\title{
Phenology of the specialist bee Colletes hederae and its dependence on Hedera helix L. in comparison to a generalist, Apis mellifera
}

\author{
Georgia Hennessy ${ }^{1}$ (D . Cassanda Uthoff ${ }^{1} \cdot$ Sema Abbas $^{1}$ - Stefano C. Quaradeghini ${ }^{1}$. Emma Stokes ${ }^{1}$. Dave Goulson ${ }^{1}$. \\ Francis L. W. Ratnieks ${ }^{1}$
}

Received: 9 July 2020 / Accepted: 2 February 2021 / Published online: 22 February 2021

(c) The Author(s) 2021

\begin{abstract}
Colletes hederae, the ivy bee, (Hymenoptera: Colletidae) has undergone large range expansions in Europe in recent years, including colonising Britain in 2001 with its original distribution limited to Western mainland Europe and the Channel Islands. It is thought to specialise on Hedera helix L. (Apiales: Ariliaceae), common ivy. However, some research has questioned this dependence. This study quantifies the foraging ecology of $C$. hederae to determine its relationship with ivy in Sussex. We quantified the phenology of ivy bloom, $C$. hederae activity and flower visitation, and pollen collection of females through pollen analysis. We also gathered equivalent data on Apis mellifera both as a comparison and to assess alternative pollen sources. The phenology of female $C$. hederae activity was highly correlated with and phonologically contained within the ivy bloom period. Pollen analysis from $C$. hederae identified ivy pollen was $98.5 \%$ of samples, significantly more than for A. mellifera $(90 \%)$. Two other plant species were identified and more common in $C$. hederae samples when ivy bloom was not at its peak. Surveys of ivy flowers surrounding the aggregations found that $C$. hederae were the most common insect (26\%) foraging on ivy. Although $C$. hederae can forage on other species, ivy was found to be an important floral resource. The results also suggest the potential for competition with A. mellifera, the only other bee present in more than small numbers on $H$. helix flowers, as although A. mellifera is a generalist, in autumn it mainly forages on ivy.
\end{abstract}

Keywords Solitary bee $\cdot$ Foraging ecology $\cdot$ Conservation $\cdot$ Plant pollinator interaction

\section{Introduction}

When a species specialises on a single food source it has a total dependence on the distribution of this resource across time and space. Herbivores can be specialists or generalists in their use of food plants. Specialisation is seen between many insect species and their host plants (Kéry et al. 2001). For example, Argynis adippe (the high brown fritillary) whose larval food plant is predominantly Viola riviniana (common dog violet, Barnett and Warren 1995) and Pieris rapae (small white butterfly) whose larvae primarily consume plant species from the cabbage family (Davies and Gilbert 1985). However, this level of specialisation is rare

Handling Editor: Isabel Alves dos Santos.

Georgia Hennessy

g.i.hennessy@sussex.ac.uk

1 Life Sciences, University of Sussex, East Sussex, Brighton BN1 9QG, UK between adult insect pollinators and their host flowers (Minckley and Roulston 2006).

Unlike other pollinator species such as butterflies and flies which only forage on pollen and nectar when in the adult stage, bees also rely on these to feed their larvae (Nicolson 2011). Nectar is predominantly an energy source, with pollen providing bees with protein, lipids and minerals which are essential for larval development (Vanderplanck et al. 2017).

Host-pollen specialisation in bees is categorised in three levels (i) polylecty, where bees collect pollen from a broad range of flowers, e.g. Apis mellifera (Köppler et al. 2007), (ii) oligolecty, where pollen is collected from a narrow range of species within a genus or related genera, e.g. Colletes halophilus (Sommeijer et al. 2009) and (iii) monolecty, where bees collect pollen from a single plant species, e.g. Hesperapis oraria (Davis et al. 2020; Müller and Kuhlmann 2008).

The floral composition of a landscape is usually heterogeneous both spatially and temporally, potentially posing a challenge for bees which are reliant on specific floral hosts. 
Species which do demonstrate a narrow foraging range will have matched phenology with their food plants (Minckley et al. 1994; González-Varo et al. 2016; Ogilvie and Forrest 2017) often with emergence of females occurring slightly before the peak floral bloom (Larsson and Franzen 2008). Cases of complete mismatch between floral host and oligolectic bee species are rare. However, sometimes emergence can be slightly out of synchrony with the floral bloom. Here, specialists have been seen to adapt and forage on other available species (Westrich 2008; Müller and Kuhlmann 2008) resulting in a suggested reclassification of the three pollen specialist categories to account for the flexibility often seen in species (Cane and Sipes 2006; Müller and Kuhlmann 2008; Cane 2020).

Colletes hederae, (Hymenoptera: Colletidae), the ivy bee, has previously been suggested as being narrowly oligolectic on pollen from Hedera helix L., common ivy (Apiales: Ariliaceae), or under one of the proposed changes to the classification system, monolectic within the Hedera genus (Cane 2020). However, studies both on museum specimens (Müller and Kuhlmann 2008) and live bees (Teppner and Brosch 2015) in Europe have suggested it may have a wider diet range. Pollen specialisation is also seen in the closely related C. succinctus and C. halophilus species, which specialise on heather species and sea aster, respectively (BWARS 2011, BWARS 2012).

Colletes hederae was only described as a new species in 1993. At that time, it was known only in the Channel Islands, France, Germany, Italy and Croatia (Schmidt and Westrich 1993). Since then, its range has spread and it is now found throughout southern and western Europe (Bischoff et al. 2005) with its range much smaller than that of its host plant species, H. helix. Since its arrival in southern England in 2001, C. hederae has spread throughout Britain. It is now recorded in multiple sites in the southern half of Britain and as far north as the Yorkshire and Lancashire coasts, $400 \mathrm{~km}$ from the first record in Dorset (BWARS 2019).

This expansion of an invasive species could potentially place pressure on the native pollinator community. This is especially the case for $C$. hederae as they are active in early autumn and forage on the main source of nectar and pollen for most pollinator species active at this time. There is growing evidence that Apis mellifera (Hymenoptera: Apidae) can compete with wild bee species for floral resources (Hudewenz and Klein 2015; Herbertsson et al. 2016) in part due to them being generalist foragers (Köppler et al. 2007) and living in large colonies. Their diverse diet, and the fact that $A$. mellifera are known to forage heavily on H. helix during the autumn (Garbuzov and Ratnieks 2014) mean that they make for an ideal comparison between the specialist $C$. hederae and can help give an indication of the floral resources available in the surrounding area as they are able to forage across large distances (Couvillon et al. 2014).
Also, by comparing these two species' activities on H. helix, it may help identify the potential competition posed by $C$. hederae on A. mellifera and other $H$. helix visiting insects.

Colletes hederae are known to have been present on the University of Sussex campus since at least 2009 (Garbuzov and Ratnieks 2014). The aim of this investigation was to quantify the foraging ecology of $C$. hederae and to determine its relationship with $H$. helix (hereafter referred to as ivy) in Sussex, an area of the UK where it has been present for approximately 10 years and is now abundant. This was achieved through (i) phenology, comparing $C$. hederae nesting and foraging activity with the local ivy bloom intensity, (ii) pollen analysis using samples collected from foraging females returning to their nests in comparison with samples from Apis mellifera hives and (iii) surveys of insects visiting ivy flowers.

\section{Methods}

\section{Study species}

\section{Colletes hederae}

Colletes hederae are medium-sized solitary bee, with females up to $13 \mathrm{~mm}$ long and males up to $10 \mathrm{~mm}$ (Falk and Lewington 2015). Female ivy bees are very similar to honey bee workers in size. Adults are mainly on the wing from late August to mid-October, coinciding with the bloom of its host plant, ivy (BWARS). Colletes hederae females nest in densely populated aggregations in the ground, with reports of up to 300 nests per $\mathrm{m}^{2}$ (Bischoff et al. 2005). A single female can produce 18 brood cells in one month of adult activity (Danforth et al. 2019). Females will collect both nectar and pollen for their brood.

\section{Apis mellifera}

In comparison to $C$. hederae, Apis mellifera are eusocial and live in large colonies with many thousands of individuals (Seeley 2009). They forage all year round, provided floral resources are available, and the temperature is above $10{ }^{\circ} \mathrm{C}$ (Seeley 1982). They collect both pollen and nectar from a variety of flower species (Köppler et al. 2007).

\section{Ivy}

In Britain, there are two species of ivy, H. helix and its tetraploid daughter species $H$. hibernica. Both are common and widespread throughout the UK, except for some parts of Northern Scotland, and are almost identical in morphology (McAllister 1990). Ivy generally grows in shaded, damp locations and is often found in woodland (Metcalfe 2005). 
It only begins to flower once mature, aged 10 years or more, where the leaves also change from being lobed to ovate (Clark 1983). Ivy flowers are pentapetalous and contain an open-type nectary, which is easily accessible to pollinators (Konarska 2014). Flowers occur in panicles of 1-6 umbels, with anthesis occurring 1-2 days before nectar secretion (Metcalfe 2005).

\section{Nest site aggregations}

Three nest aggregations of $C$. hederae were studied in September and October 2019. One was in the garden of a house in the village of Falmer, East Sussex, approximately $300 \mathrm{~m}$ from the edge of the University of Sussex Campus $(50.864189,-0.079073)$. The second was on the University of Sussex campus $(50.866395,-0.089911)$ on a small (c. $115 \mathrm{~m}^{2}$ ) grassy slope, and the third was located on the edge of the town of Lewes, approximately $5 \mathrm{~km}$ to the East of Falmer (50.880111, - 0.000481). The Lewes aggregation consisted of two small aggregations (c. $23 \mathrm{~m}^{2}$ each) which were present on the front lawn of neighbouring houses. Due to their close proximity, $20 \mathrm{~m}$ apart, they were combined for analysis.

\section{Pollen collection and analysis}

\section{Colletes hederae}

Pollen was collected at all 3 aggregations from foraging females with visible pollen loads returning to their nests. Once caught, a bee was transferred to a honey bee queen marking cage (Pixnor, China) where using a toothpick pollen was scraped from both hind tibia and placed in individual Eppendorf tubes and stored for later analysis. Once pollen was collected, bees were released. Between 10 and 20 samples were collected per week per aggregation. Sampling started when females were first returning to their nests with pollen loads until they were no longer active at the nesting sites. For the Falmer aggregation, this was from 16 September to 21 October, and for the Sussex University (SU Campus) and Lewes aggregations, this was from 16 September to 7 October.

For pollen identification, each sample was then placed on a microscope slide and mixed with a small volume of glycerine jelly stained with Fuchsin dye. A cover slip with a small grid was used allowing the sample to be divided into equally sized quadrats. The section of sample to be analysed was chosen at random, and the number of pollen grains per plant species within each section was counted. Once all the grains within a section were counted, a new quadrat would be chosen at random and the process completed until 200 grains had been counted. If there were not 200 grains in a sample, the entire sample was analysed. Pollen identification and counting occurred using a compound microscope at $\times 400$ magnification using both a pollen reference collection from flowers surrounding the aggregations and a pollen identification guide (Sawyer and Pickard 1981). For each sample, the proportion of each species present was calculated. Classification to species level was attempted. However, due to similarities between species, this was not always possible e.g. Asteraceae species.

\section{Apis mellifera}

Pollen was also collected from four Apis mellifera colonies in hives at the Onion Field apiary, c. $40 \mathrm{~m}$ from the Falmer aggregation of $C$. hederae. To collect pollen from A. mellifera hives, a standard pollen trap with a $5 \mathrm{~mm}$ plastic mesh, (E.H Thorne UK) was attached over the entrance of each hive. This mesh results in pollen from returning foragers being knocked from the pollen baskets into a tray. Mesh was put into position one day per week from 8:30 to $17: 30$ to encompass an entire foraging day on days of good weather for bee flight (above $10{ }^{\circ} \mathrm{C}$ and no rain). Each sample comprised the pellets collected from one hive on one day. The survey period was 26 August to 28 October with no pollen collected on the week of 21 October as there was no suitable foraging weather.

In most cases the daily sample from a hive was large so a sub sample of 50 randomly chosen pellets was used. Occasionally (2/25) the sample was less than 50 pellets, and all were identified. Occasionally hives returned no pellets (8). Each pellet was of a single colour indicating that the pollen was collected from a single plant species. This is expected as A. mellifera are flower constant, with almost all foragers visiting only one species of plant per foraging trip (Free 1963).

Pellets were separated by colour, and if a colour had more than 10 pellets, then 10 were randomly chosen and analysed. If all 10 were the same species, the remaining pellets of that colour were tallied together and not examined under the microscope. A small amount from each pellet was mounted onto a slide, as for $C$. hederae, mixed with glycerine jelly stained with Fushin dye and examined at $\times 400$ under a light microscope using the same quadrat system as with $C$. hederae. Pollen was again identified to species where possible using the same pollen identification guide as with $C$. hederae (Sawyer and Pickard 1981).

\section{Ivy bloom period}

To determine the bloom period of ivy, all patches of ivy present within $300 \mathrm{~m}$ of each aggregation were surveyed and the bloom quantified. Foraging range of solitary bees is thought to correlate with intertegular (IT) span and body length, which for $C$. hederae (IT span 1.5-2 mm, body length $13 \mathrm{~mm}$ Female, GH Pers obs) indicates a foraging distance 
of $500 \mathrm{~m}$ (Gathmann and Tscharntke 2002; Greenleaf et al. 2007). Due to the high local abundance of ivy and because bee foraging distances reduce with increased floral resources (Gathmann et al. 1994, Gathmannn and Tscharntke 2002), $300 \mathrm{~m}$ was chosen as a practical and ecologically relevant survey distance which would give a good indication of the local ivy flower availability surrounding the aggregations.

Once per week from 9 September to 21 October 2019 fixed survey routes within $300 \mathrm{~m}$ of each aggregation were walked. Mature ivy is often found in abundance along walls, hedges, and trees. In order to survey, the ivy present was allocated to patches $2 \mathrm{~m}$ long and $2 \mathrm{~m}$ high, and each of these patches was given a score to indicate the proportion of flowers in bloom. For practical reasons, we had to limit the height surveyed to $2 \mathrm{~m}$ even though some ivy was higher. This ensured that flower assessment was accurate, as above $2 \mathrm{~m}$, it was not possible to accurately determine the bloom stage of flowers. Each patch was given a score to determine its flowering status: (0) buds only, with no flowers open or all flowers have finished blooming; (1) 0-30\% of flowers open; (2) 30-80\% of flowers open and (3) Peak bloom, $80-100 \%$ of flowers open (Fig. 1). This classification was adapted from Garbuzov and Ratnieks 2014. For analysis, the midpoint percentage of flowers open for each patch was determined (e.g. a score of 1 indicates $15 \%$ of flowers open). The average percentage of open flowers for each survey week was calculated as the average of all flower patches for each site.

\section{Colletes hederae activity at nest aggregation}

Activity was quantified by the number of $C$. hederae individuals on the wing at each aggregation. This was determined by sweeping with the same insect net at each aggregation and calculating the average number of male and female $C$. hederae caught per sweep. Sweeps were conducted on days with weather good enough for insect flight (sunny, minimum temperature $11^{\circ} \mathrm{C}$ ) between 10:00 and 16:00. Three sweeps of the entire aggregation were done each day with surveys attempted every day. However, due to weather conditions, this was not always possible. Bee activity surveys occurred between 9 September until 21 October as this covers the main period when $C$. hederae are on the wing (Falk and Lewington 2015).

\section{Insect surveys}

Insects on ivy flowers were surveyed in the village of Falmer and on the University of Sussex Campus with identification by eye in the field. Surveys in Falmer were within $300 \mathrm{~m}$ of the Falmer aggregation, with surveys on the University of Sussex Campus occurring between 500 and $650 \mathrm{~m}$ away from the SU aggregation. Within these sites, several distinct areas of ivy flowers were surveyed, with the specific patches used varying between weeks as areas came in and out of bloom. Surveys took place at approximately weekly intervals and corresponded with the main ivy bloom from 2 September to 21
Fig. 1 Ivy flowers at different stages of bloom. a Flowers have not yet opened so would be classed as a 0 (Christina Pictures 2016), b Open flowers. Depending on the number open within a patch a score ranging from 1 to 3 would be given (Nick Upton 2018), c A patch of flowers which would be classified as a 3 , full bloom, as more than $80 \%$ of flowers are open (Alan Fryer 2007), d Flowers have 'gone over' and berries have formed, a score of 0 (Linda Crampton 2017)
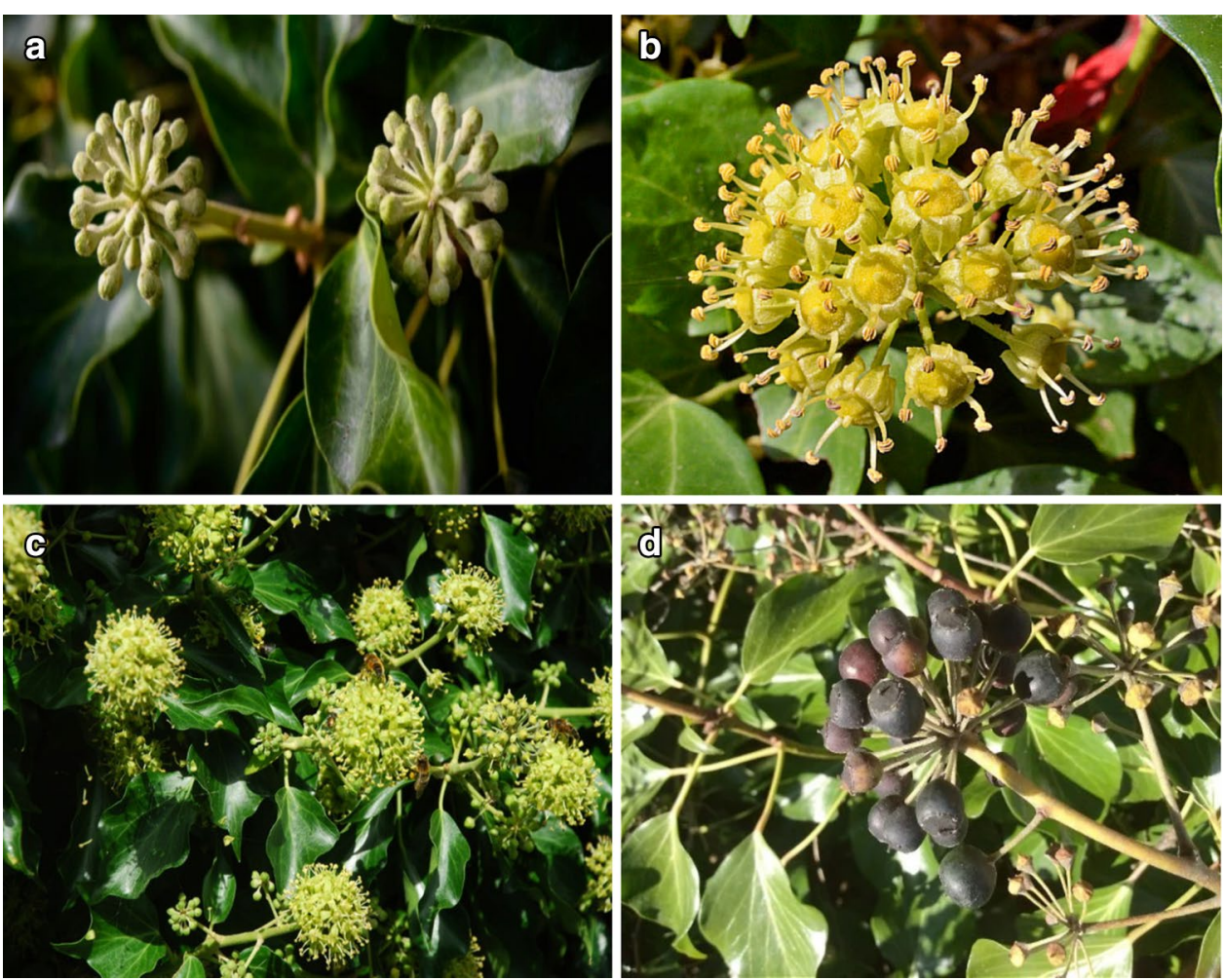
October. Counts of insects on flowers were made until a total of 100 insects were identified at each of the two study areas. On some weeks, fewer than 100 insects were counted on the Campus site ( $n=79,23$ September, $n=5014$ October, $n=86$ 21 October). On a few of the survey weeks, data were collected over multiple days (5 occasions). Data were collected at times of weather good enough for insect flight (temperatures ranged from 10 to $21{ }^{\circ} \mathrm{C}$ ) between 10:40 and 16:00. All ivy flower visitors were identified to the following taxa: $1-$ Colletes hederae, 2-Apis mellifera, 3-Bombus, 4-Apoidea (other bees), 5-Vespula vulgaris, 6-Syrphidae (Hoverflies), 7Diptera (other flies) and 8-Lepidoptera (butterflies). The number of male and female $C$. hederae was noted, as was the proportion of female $C$. hederae and A. mellifera with visible loads of pollen.

\section{Statistical analysis}

The relationship between female $C$. hederae activity at aggregations and ivy bloom intensity (percentage of open flowers) was analysed using a generalised mixed effect model (GLMM) with a negative binomial distribution aggregation site as a random factor. The response variable was the number of females caught per survey. The predictor variables were percentage of open flowers and survey week. Week was included in the model as a quadratic function as this was found to best fit the data.

To test if the average proportion of ivy pollen across the entire survey period differed between $C$. hederae aggregations, a Kruskall-Wallis test was run with a follow on post hoc Dunn test with Bonferroni correction. To determine if the proportion of ivy pollen present changed over time for each $C$. hederae aggregation, a Chi-square test for heterogeneity was run for each aggregation comparing ivy proportions for each survey date.

To determine if the proportion of ivy collected differed between $A$. mellifera and $C$. hederae, a Wilcoxon signed rank test was performed with percentage of ivy as the dependent variable and bee species as the independent. Only pollen collected by A. melifera hives during the same period that female C. hederae were on the wing was used in the comparison (9 September to 14 October). Pollen collected from $C$. hederae at the Lewes nest aggregation was not compared with A. mellifera because this aggregation was located beyond the foraging range of the A. mellifera hives. All graphs were made, and tests run using $\mathrm{R}$ ( $\mathrm{R}$ Core team, version 3.4.2).

\section{Results}

\section{Colletes hederae pollen composition}

A total of 203 pollen samples were collected from individual female $C$. hederae, 101, 40 and 62 from the nest aggregations at Falmer, Sussex University Campus (SU Campus) and Lewes, respectively. Ivy pollen was present in $100 \%$ of the samples and on average was $98.5 \pm 0.29 \%$ SE of the pollen grains counted. In 65\% (131/203) of the samples, ivy was the only species identified. Ivy pollen proportions were high at all three locations. However, there was a significant difference between Falmer and Lewes $(99.1 \pm 0.22 \%$ SE vs $97.3 \pm 0.76 \%$ SE, Dunn post hoc test, $\chi^{2}=10.40, \mathrm{df}=3, P=0.002$, Fig. 3a). There was no difference between SU Campus $(98.7 \pm 0.60 \%$ SE) and Falmer $(P=0.84)$ and Lewes $(P=0.70$, Fig. 2a).

There was no significant difference between the proportion of ivy pollen in samples across weeks for Falmer $\left(\chi^{2}=1.49, \mathrm{df}=5, P=0.91\right)$. However, there was for SU Campus $\left(\chi^{2}=11.9, \mathrm{df}=3, P=0.007\right)$ and Lewes $\left(\chi^{2}=15.79, \mathrm{df}=3\right.$, $P=0.001)$. Figure 3 a shows that the lowest proportion of ivy in samples for both Lewes and SU Campus were from the week commencing 16 September (92\% Lewes, $94 \%$ SU), at the start of the ivy bloom. After this, the proportion of ivy pollen present per sample increased to over $98 \%$ at both.

Pollens from four other plant groups were identified (Table 1). Across aggregations, the second most abundant was wild clematis, Clematis vitalba (Ranunculales: Ranunculaceae), which was present in $21 \%$ of samples, $0.89 \pm 3.39 \%$ SE on average per sample (Table 1). The other three groups identified included bramble, Rubus fruticosus L. (Rosales: Rosaceae), Asteraceae species and birds foot trefoil, Lotus corniculatus (Fabales: Fabaceae). All pollen species identified were from wild flower species. Asteraceae pollen was not observed in samples from the SU Campus aggregation, and L. corniculatus was only identified in samples from Falmer. Rubus fruticosus and C. vitalba were found in samples from all three aggregations.

Clematis vitalba was also the second most common plant species in samples from Lewes $(1.65 \pm 0.72 \%$ per sample, present in 14/62 samples). On the week of 16 September, when ivy proportion was at its lowest for Lewes and SU Campus aggregations, the most common other pollen identified was $C$. vitalba. In Lewes, it accounted for 8\%, and in SU Campus, it accounted for $4 \%$ of the pollen identified that week.

\section{Apis mellifera pollen composition}

A total of 1187 pollen pellets were analysed from 25 sample occasions from 9 days. There was no significant difference in the proportion of ivy pollen among the four A. mellifera 


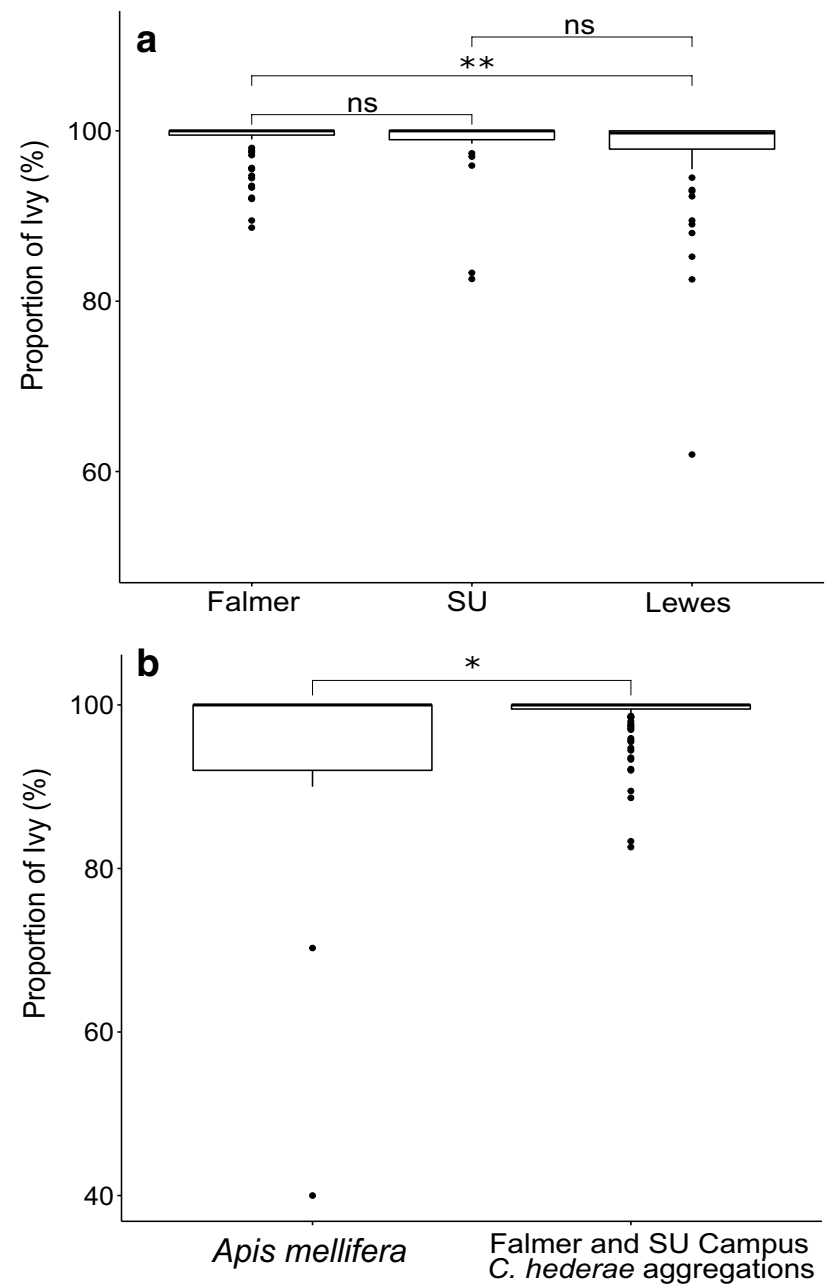

Fig. 2 Proportion of ivy pollen in samples between 16 September and 21 October, the period Colletes hederae females were foraging for pollen in a $C$. hederae samples for each aggregation and $\mathbf{b}$ Apis mellifera colonies and the Falmer and SU Campus aggregations. Due to no difference in ivy proportion between Falmer and SU Campus, these were combined for comparison with A. mellifera. Lewes was not compared with $A$. mellifera due to the aggregation being located beyond the foraging range of the $A$. mellifera hives. * indicates a significance of $P<0.05$ and $* *$ indicates a significance of $P<0.001$. NS means no significant difference between the groups was identified

hives (Kruskall Wallis, $\mathrm{df}=3, P=0.538$ ), all of which were located at Falmer, so they were pooled for analysis.

Ivy was present in $92 \%(23 / 25)$ of the A. mellifera samples, and for the whole survey period (26 August to10 November), on average per sample was $67 \%$ of the pellets identified (Table 1). The second most abundant pollen type was $C$. vitalba $(10.56 \pm 3.27 \%$ SE of pellets, Table 1$)$. When examining the presence of ivy pollen in samples only in the period that overlaps with $C$. hederae pollen foraging (16 September to 14 October), ivy was present in all samples and was $90 \%$ of pollen pellets identified. Throughout the whole survey period, pollens from eight
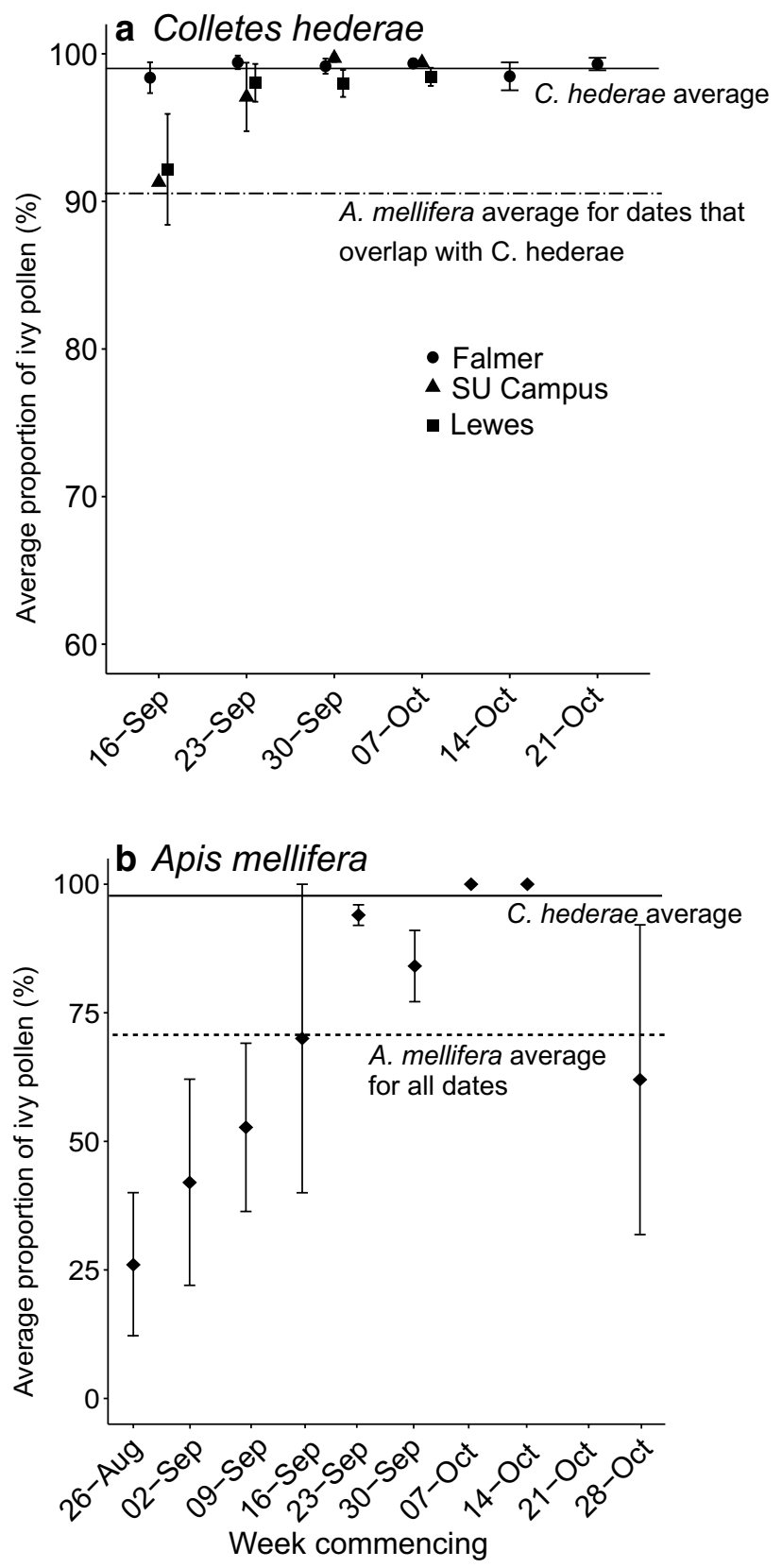

Fig. 3 Mean proportions of ivy pollen present in samples for each survey week for a $C$. hederae and $\mathbf{b}$ A. mellifera. The dashed line shows the average proportion for dates that overlap with $C$. hederae flight for A. mellifera, the solid line shows the same for $C$. hederae and the dotted line shows the average proportion for the entire sample period for $A$. mellifera (26 August to 28 October). For $C$. hederae only, samples from the Falmer aggregation were collected for the final two survey weeks due to low levels of activity at the other two aggregations (21-28 October)

other plant groups were also identified (Table 1). Rubus fruticosus was present in more samples than $C$. vitalba but accounted for a smaller proportion of identified pellets $(R$. fruticosus $7.29 \pm 2.48 \%$ SE vs C. vitalba $10.56 \pm 3.27 \%$ $\mathrm{SE})$. During the period which overlapped with $C$. hederae 
Table 1 Plant species found in pollen samples from Colletes hederae and Apis mellifera

\begin{tabular}{|c|c|c|c|}
\hline Plant species & $\begin{array}{l}\text { Present in individual bee }(C . h) \text { or } \\
\text { hive }(A . m) \text { per week }(\%)\end{array}$ & $\begin{array}{l}\text { Mean proportion across } \\
\text { samples }(\%)\end{array}$ & $\begin{array}{l}\text { SE standard } \\
\text { error }(\%)\end{array}$ \\
\hline \multicolumn{4}{|c|}{ Colletes hederae: 16 September-21 October } \\
\hline Hedera sp. & $100 \%(202 / 202)$ & 98.5 & $0.29 \%$ \\
\hline *Lotus corniculatus & $0.5 \%(1 / 202)$ & 0.009 & $0.009 \%$ \\
\hline Clematis vitalba & $21.3 \%(43 / 202)$ & 0.89 & $3.39 \%$ \\
\hline Rubus fruticosus & $20.3(41 / 202)$ & 0.61 & $3.39 \%$ \\
\hline Asteraceae sp. & $1.45 \%(3 / 202)$ & 0.02 & 0.007 \\
\hline \multicolumn{4}{|c|}{ Apis mellifera: 26 August-28 October (whole period of ivy bloom) } \\
\hline Hedera sp. & $92 \%(23 / 25)$ & 67.10 & $7.03 \%$ \\
\hline Clematis vitalba & $44 \%(11 / 25)$ & 10.56 & $3.27 \%$ \\
\hline Rubus fruticosus & $48 \%(12 / 25)$ & 7.29 & $2.48 \%$ \\
\hline Papaver sp. & $36 \%(9 / 25)$ & 5.92 & $2.27 \%$ \\
\hline Dahlia sp. & $16 \%(4 / 25)$ & 1.61 & $0.92 \%$ \\
\hline Brassica napus & $4 \%(1 / 25)$ & 0.32 & $0.32 \%$ \\
\hline Phacelia tanacetifolia & $4 \%(1 / 25)$ & 0.24 & $0.24 \%$ \\
\hline Hypericium sp. & $4 \%(1 / 25)$ & 0.08 & $0.08 \%$ \\
\hline Epilobium & $4 \%(1 / 25)$ & 0.08 & 0.08 \\
\hline Unknown & $4 \%(1 / 25)$ & 2.24 & $2.24 \%$ \\
\hline \multicolumn{4}{|c|}{ Apis mellifera: 16 September-21 October (C. hederae foraging period) } \\
\hline Hedera sp. & $100 \%(13 / 13)$ & 90.80 & $4.82 \%$ \\
\hline Clematis vitalba & $39 \%(5 / 13)$ & 5.83 & $3.50 \%$ \\
\hline Rubus fruticosus & $15 \%(2 / 13)$ & 0.77 & $0.53 \%$ \\
\hline Papaver sp. & $23 \%(3 / 13)$ & 2.62 & $1.75 \%$ \\
\hline
\end{tabular}

For $C$. hederae, data are for all aggregations and for A. meliffera all hives, which were all at the Falmer location but also close to the SU campus aggregation. The number of samples where each species was present is shown together with the average proportion per sample. Species which were found in both $C$. hederae and A. mellifera samples are in bold. The asterisk, *, indicates a potential contamination as was only present in one sample. Proportions for both the entire survey period and the period that overlaps with C. hederae pollen foraging are shown for A. mellifera activity, three other plant species were identified in $A$. mellifera samples, $C$. vitalba, $R$. fruticosus and a species which was not found in $C$. hederae samples, poppy (Papaver sp., Table 1).

There was a significant difference in the proportion of ivy pollen in samples between weeks for A. mellifera colonies $\left(\chi^{2}=277.61\right.$, df $=8, P<0.0001$, Fig. $\left.3 b\right)$. The highest proportions were in the weeks commencing 7 October and 14 October when it was $100 \%$ of pellets. The lowest proportion was in the week of 26 August, with on average $25 \%$ of pellets being ivy (Fig. 3b).

There was a significantly higher proportion of ivy pollen in $C$. hederae samples from 16 September to 14 October from the Falmer and SU aggregations compared to those of A. mellifera (Wilcoxon rank sum test, $W=663$, $P=0.044,98.9 \pm 0.23 \%$ vs $90.8 \pm 4.82$, Fig. $2 b$ ). Pollen from the Lewes aggregation was not compared with the A. mellifera colonies because it was located outside the foraging range of the A. mellifera pollen trap hives (Couvillon et al. 2014).

\section{Colletes hederae phenology}

Falmer was the aggregation with the highest sweep counts, averaging 28 males and females combined versus 11.7 for Lewes and $<1$ for SU Campus. Due to the low numbers at SU Campus, it was not included in the phenology analysis. For both Falmer and Lewes aggregations, male activity peaked before females (Fig. 4), and males were most active on the week of 9 September $(\bar{x}=68.3 \pm 27.5 \mathrm{SE})$ and females on the week of 30 September $(\bar{x}=17.9 \pm 1.98$ SE). This peak in female activity corresponded with the peak in ivy bloom, with the highest percentage of flowers open $(32.3 \%)$ also on the week of 30 September. There was a significant relationship between female activity and percentage of flower bloom (GLMM, $F_{1,61}=37.6$, $\mathrm{P}<0.001)$. Female activity also significantly changed with week (GLMM, $F_{1,59}=39.8, \mathrm{P}<0.001$ ) following a quadratic pattern. Male activity peaked when on average only $20 \%$ of flowers were in bloom (Fig. 4). 


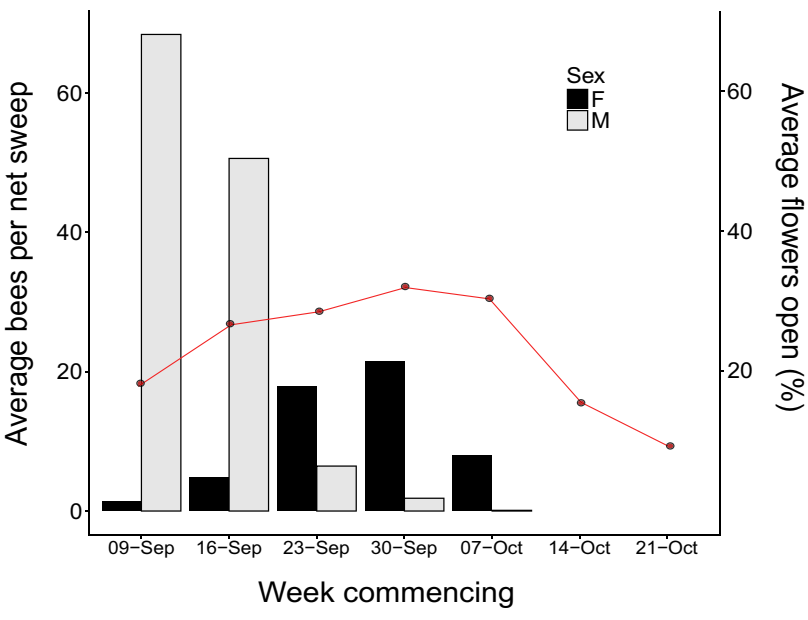

Fig. 4 Mean number of $C$. hederae caught per sweep with an insect net per week. The red line indicates the average number of ivy flowers open for the corresponding week. Data have been pooled from Lewes and Falmer for both bee activity and flower bloom. No $C$. hederae were caught on the weeks of 14 and 21 October

\section{Insects on ivy flowers}

A total of 14 insect groups and 1565 insects were recorded foraging on ivy flowers during the survey period (weeks beginning 2 September to 21 October) across the two survey sites (SU Campus and Falmer). The most common species was $C$. hederae which accounted for $25.8 \%(403 / 1565)$ of sightings, followed by hover fly species $(23.5 \%, 367 / 1565)$ and A. mellifera $(22.9 \%, 359 / 1565)$. Few other bees were seen. Bumble bees (Hymenoptera: Apidae) comprised from 0 to $3 \%$, with an average of $1 \%$ of insects seen per week (Table 2). Only one other bee, genus Andrena (Hymenoptera: Andrenideae), was seen throughout the whole survey period.

At the beginning of the survey period, the $C$. hederae seen on ivy flowers were mainly male (71\% week of 2 September and $80 \%$ week of 9 September). Subsequently, the proportion of males reduced with females being the most abundant. In the week of 16 September, females accounted for $66 \%$ of $C$. hederae seen and then averaged $95 \%$ in the remaining survey weeks. Initially, most females seen did not have visible pollen loads in their scopa (first two survey weeks average of $16.7 \%$ across sites, Fig. 5a). This increased throughout the survey period with an average of $88.0 \%$ of females with pollen between 16 September and 21 October, reaching a peak of $100 \%$ by the final week ( 21 October).

Colletes hederae sightings reached their peak on the week of 30 September with over $50 \%$ of insects being $C$. hederae across both sites (Fig. 5b). This also corresponds with the peak ivy bloom and when females were most active at the aggregations (Fig. 4). After this week, the
Table 2 The insect groups identified foraging on ivy during surveys at (A) Falmer (B) Campus

\begin{tabular}{|c|c|c|}
\hline Species/Group & $\begin{array}{l}\text { Average weekly pro- } \\
\text { portion }(\% \pm \mathrm{SE})\end{array}$ & $\begin{array}{l}\text { Total } \\
\text { propor- } \\
\text { tion }(\%)\end{array}$ \\
\hline \multicolumn{3}{|l|}{ (A) Falmer } \\
\hline Colletes hederae & $29.8 \pm 7.94$ & $\begin{array}{l}30.1 \\
N=256\end{array}$ \\
\hline Apis mellifera & $33.4 \pm 4.20$ & $\begin{array}{l}31.4 \\
N=267\end{array}$ \\
\hline Bombus & $1.13 \pm 0.35$ & $\begin{array}{l}1.06 \\
N=9\end{array}$ \\
\hline Vespula vulgaris & $11.6 \pm 3.92$ & $\begin{array}{l}10.6 \\
N=90\end{array}$ \\
\hline Syrphideae (Hoverflies) & $16.44 \pm 4.58$ & $\begin{array}{l}18.6 \\
N=158\end{array}$ \\
\hline Diptera (other flies) & $7.94 \pm 2.38$ & $\begin{array}{l}7.18 \\
N=61\end{array}$ \\
\hline Lepitoptera (Butterflies) & $1.19 \pm 0.53$ & $\begin{array}{l}1.06 \\
N=9\end{array}$ \\
\hline \multicolumn{3}{|l|}{ (B) SU Campus } \\
\hline Colletes hederae & $19.3 \pm 5.05$ & $\begin{array}{l}20.6 \\
N=147\end{array}$ \\
\hline Apis mellifera & $14.6 \pm 2.95$ & $\begin{array}{l}12.9 \\
N=92\end{array}$ \\
\hline Bombus & $0.25 \pm 0.25$ & $\begin{array}{l}0.28 \\
N=2\end{array}$ \\
\hline Apoidea (other bees) & $0.001 \pm 0.001$ & $\begin{array}{l}0.14 \\
N=1\end{array}$ \\
\hline Vespula vulgaris & $25.0 \pm 6.07$ & $\begin{array}{l}23.5 \\
N=168\end{array}$ \\
\hline Syrphideae (Hoverfly species) & $27.8 \pm 6.48$ & $\begin{array}{l}29.3 \\
N=209\end{array}$ \\
\hline Diptera (other flies) & $12.9 \pm 1.09$ & $\begin{array}{l}12.3 \\
N=88\end{array}$ \\
\hline Lepidoptera (Butterflies) & $1.13 \pm 0.99$ & $\begin{array}{l}1.26 \\
N=9\end{array}$ \\
\hline
\end{tabular}

The average weekly proportion for each insect group or species is shown along with the total proportion for the whole survey period. Data were collected from a total of 8 samples days and $N$ indicates the total number of individuals recorded over the whole survey period

proportion of $C$. hederae decreased to $5 \%$ by the week of 14 October and $1.5 \%$ on the final survey week (21 October). Overall, Falmer had a higher proportion of $C$. hederae compared to the campus site ( $30 \%$ vs $21 \%$ ).

By contrast, although $A$. mellifera proportions did fluctuate between 10 and $33 \%$, averaging 23\% per week, they did not show the clear increasing and then decreasing trend seen by $C$. hederae. The proportion of $A$. mellifera workers collecting pollen was higher later in the survey period, with an average of $84 \%$ for the last two survey weeks (14-21 October). Prior to this, $51 \%$ of females were seen collecting pollen (Fig. 5a). 


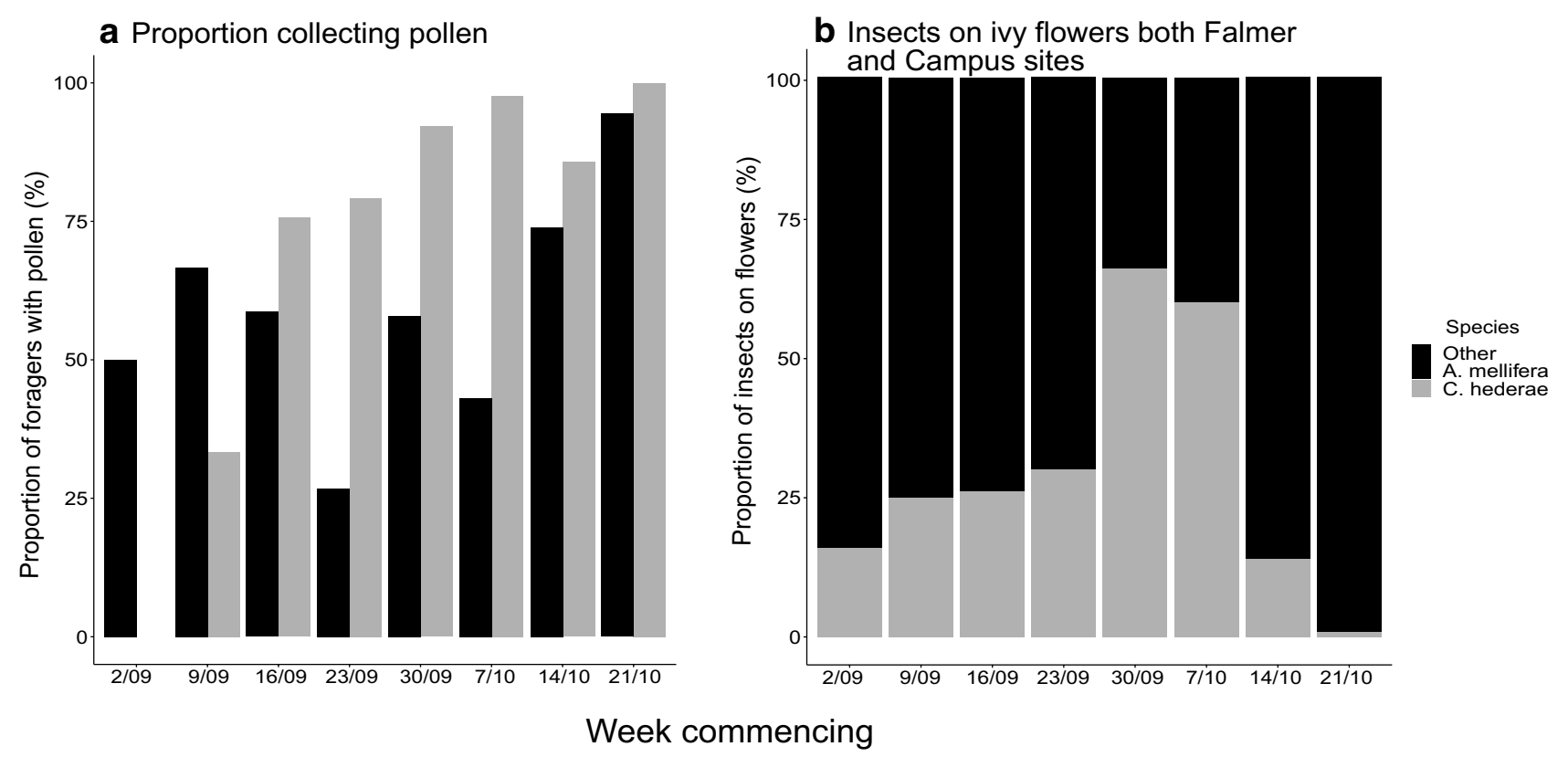

Fig. 5 a Proportion of female A. mellifera and C. hederae which were seen to be carrying ivy pollen in their scopa, b proportion of different insect taxa seen foraging on ivy flowers with both SU Campus

\section{Discussion}

Our results show the importance of ivy, to the ivy bee, Colletes hederae. Almost all the pollen grains identified from females returning to the nest aggregation were ivy (98.5\%). In addition, the phenology of female nesting and foraging activity took place exclusively within the ivy bloom period with peak activity at the aggregation and on flowers both coinciding with peak bloom. In comparison, although honey bees, Apis mellifera, collected a large proportion of pollen $(90 \%)$ from ivy during the same period, this was significantly lower than for the $C$. hederae. In addition, $A$. mellifera pollen collection on ivy did not show such a tight relationship with the ivy bloom as that of the $C$. hederae.

\section{Colletes hederae pollen composition}

The foraging behaviour of $C$. hederae in this study can be considered eclectic oligolecty which is defined as $95 \%$ or more of the grains collected belong to the same genus and found in 95\% or more of the pollen loads (Müller and Kuhlmann 2008). Previous work studying pollen from $C$. hederae females has shown that they have a high association with ivy but have also highlighted how the proportion of ivy pollen collected can vary, depending on the floral resources available. Bischoff et al. (2005) sampled 15 pollen loads and 20 cells of $C$. hederae from aggregations in Dirmstein, Germany; all samples were $100 \%$ ivy pollen. In contrast, Müller and Kuhlmann (2008) examined pollen taken from museum site and Falmer site combined. At the SU Campus site weeks 23 September, 14 and 21 October, fewer than 100 insects were surveyed. All other weeks, 100 insects were counted at each site

specimens and found that only $78 \%$ of samples contained pollen from only ivy, and that on average, it was $88 \%$ of the sample. However, inferring diet breadth from museum specimens can, for example with Andrena dunninigi, result in higher foraging diversity than is seen in observations or from pollen collected from living females (Johnson 1984). The most common other species identified in $C$. hederae pollen samples included $C$. vitalba and $R$. fruticosus, and for the aggregations at Lewes and SU Campus, the proportions of these species were significantly higher at the beginning of the females flight season. This flexible foraging behaviour is seen in many oligolectic species (Bischoff 2003; Ritchie et al. 2016; Ogilvie and Forrest 2017) and has been previously reported for $C$. hederae and the closely related $C$. succinctus (BWARS 2011). Westrich (2008) identified pollen from multiple species during the first half of $C$. hederae flight period. However, once ivy began to bloom, $C$. hederae began to collect pollen solely from ivy (Westrich 2008). In the week where $C$. hederae samples from the Lewes, aggregation contained the smallest proportion of ivy (92\%), ivy flowers had still not reached their peak bloom, with on average patches only having $20 \%$ of flowers open. This indicates that $C$. hederae females will collect pollen from other species.

There was a difference in the proportion of ivy present in samples among the aggregations, with bees nesting in Lewes having significantly less (97\% vs 99\%). The Lewes aggregation was in a suburban setting, and although there was a high abundance of ivy (61 two-metre patches surveyed), the 
densest patches were located approximately $150 \mathrm{~m}$ from the aggregation. This is further than for both Falmer $(<50 \mathrm{~m})$ and SU Campus $(100 \mathrm{~m})$. This may have resulted in individuals reaching other flower species before locating an abundant source of ivy.

\section{Phenology}

Although $C$. hederae females did gather pollen from other species, our results indicate that female activity is highly correlated with and is contained within the ivy bloom period, with female activity peaking at the same time as the ivy bloom. By contrast, male activity did not synchronise with ivy bloom, peaking when only $20 \%$ of flowers were open on average. This is probably due to males not having to collect pollen for larval food; therefore, there is less reliance on the specific host plant. Males in this study were seen foraging on a range of flowers in August before the ivy bloom, including the wild flowers, bristly oxtongue (Helminthotheca echioides) and great willowherb (Epilobium hirsutum) and garden flowers, Helenium variety Sahin's Early Flowerer, indicating less floral specialisation. Differences in male and female foraging preferences are seen in other oligolectic species (Ritchie et al. 2016) and may also be due to this reduced synchronisation between males and the main host plant species.

\section{Comparison of pollen composition between $C$. hederae and $A$. mellifera}

Colletes hederae pollen samples contained significantly higher proportions of ivy compared to A. mellifera, (98\% vs $90 \%)$. Previous work on ivy has shown its importance to $A$. mellifera colonies in autumn. Garbuzov and Ratnieks (2014) found the similar result of ivy being $89 \%$ of pollen pellets in the months of September and October. Even when A. mellifera are most reliant on ivy, when there is not much else to forage on near the end of autumn, $C$. hederae still collects proportionally more ivy pollen (Fig. 3a).

Individual A. mellifera workers are known to be flower constant (Grant 1950), usually foraging on only one species of flower per foraging trip. This was seen in our results with all pellets containing only one species of pollen. This is in contrast with $C$. hederae where only $65 \%$ of samples contained a single species. It has been suggested that whether a bee remains constant or not on a foraging trip depends on time and distance between it leaving a flower and then encountering another of the same type (Chittka et al. 1997). At the beginning and end of the ivy bloom period, patches would often have inflorescences where only a few flowers were open, with these spread throughout the patch. The two main other sources of pollen for $C$. hederae, C. vitalba and $R$. fruticosus, often grow along walls and in hedges and in wooded areas and were often found nearby or intermingled with ivy, which would facilitate multi-species foraging. Often, only a small number of pollen grains from these other plant species were found in samples, perhaps indicating collection from only a few flowers. It is possible that pollen collection was incidental when the female was primarily collecting nectar. However, ivy flowers produce large amounts of nectar, which suggest that other flowers do not need to be visited to gather it. However, other species of oligolectic bees have been seen to have a wider breadth of diet for nectar other than their host-pollen plant (Wcislo and Cane 1996; Cane and Sipes 2006). Surveys of these other plant species would be required to identify if females are seen foraging for nectar.

\section{Insects foraging on ivy flowers}

Colletes hederae was the most numerous insect foraging on ivy flowers across the survey period (26\%). However, this proportion varied between weeks, depending on the ivy bloom. The proportion of A. mellifera each week also fluctuated. However, in contrast to $C$. hederae, A. mellifera proportions did not show any consistent trend with the ivy bloom. With $C$. hederae, the proportion of females collecting pollen increased as more ivy flowers came into bloom. This was also the case with A. mellifera, with the proportion collecting pollen increasing in the final 3 weeks of the survey period. This increase is most likely due to the lack of other available flowers, rather than a specific reliance on ivy, and the need for pollen to rear brood and to store. Both A. mellifera and $C$. hederae collect pollen to feed brood. However, $C$. hederae females must first mate and excavate a nest before they have larvae to provision (Schäffler and Dötterl 2011), unlike A. mellifera. Before this point, pollen collection is not required, but energy from nectar is needed for nest digging and cell building, perhaps explaining the low proportions of females in ivy flowers collecting pollen early in the survey period.

There was a difference in the proportion of $C$. hederae seen foraging on ivy between the sites with Falmer having a higher proportion compared to SU Campus (30\% vs $21 \%$ ). The Falmer aggregation was the largest of the three in this study. In 2018, it was estimated to have over 4000 nests, versus only 115 at SU Campus (Hennessy et al. 2020). This suggests proximity to large nesting sites is an important factor in determining the presence of foraging $C$. hederae. This makes sense as $C$. hederae have an estimated foraging distance of approximately $500 \mathrm{~m}$ (Greenleaf et al. 2007), meaning local densities of both ivy and $C$. hederae will have a major effect on the numbers foraging on a specific patch. 


\section{Potential for competition}

Colletes hederae has experienced a large geographic range expansion in the last 20 years throughout Western Europe (Dellicour et al. 2014). This expansion includes Britain, with the first sighting of $C$. hederae in Dorset in 2001 (Cross 2002).

Colletes hederae is an invasive species to the $\mathrm{UK}$, and as seen with the Falmer aggregation in this study, can nest in high densities and be the most abundant insect on ivy flowers. Previous surveys of insects on ivy flowers, completed in 2011 in the same location found C. hederae to be only $3 \%$ of the total insects recorded (Garbuzov and Ratnieks 2014). The proportion seen in this study (26\%) is much higher than in 2014, perhaps indicating how quickly this species can build up to become extremely abundant, approximately equalling A. mellifera in an area with numerous hives. This raises the question as to whether $C$. hederae may be harmful to native species via competition for floral resources. In this study, we identified 14 different insect groups. Of these, only bees collect pollen to provision nests. Hoverflies (Diptera: Syrphidae) consume small amounts of pollen for their own use as an adult (Hickman et al. 1995) but Vespula vulgaris (Hymenoptera: Vespidae), butterflies (Lepidoptera) and other flies (Diptera) consume only nectar (Norris 1936; Larson et al. 2001). These taxa will utilise much less of the ivy resources compared to $C$. hederae and A. mellifera. However, competition may still occur for nectar resources, as $C$. hederae will not only collect pollen for developing larvae, but also nectar. There was no evidence of antagonistic behaviour between foraging $C$. hederae and other flower visitors to ivy. However, exploitative competition through reduction of resources is seen in other systems (Balfour et al. 2015; Wignall et al. 2020). Evidence of an invasive solitary bee influencing a local pollinator species has been seen with introduced Anthidium manicatum (wool carder bee), where native Bombus impatiens do not forage on patches where A. manicatum are present (Graham et al. 2019). However, A. manicatum males are highly aggressive, likely actively excluding other foraging insects, which is not seen with $C$. hederae. Although floral resources are relatively limited when $C$. hederae are active in the autumn (Couvillon et al. 2014), ivy is highly abundant, and most other bee species are no longer active (Goulson 2003), perhaps reducing competition. The number of foraging $C$. hederae on ivy was similar to the eusocial A. mellifera, a species which some research suggests is capable of outcompeting wild bees through exploitative competition due to their large numbers (Henry and Rodet 2018) but which can itself be outcompeted in this way (Balfour et al. 2015). Considering the strong dispersal ability of the species, the fact its parasites are not yet found in the UK (Dellicour et al. 2014) and that females can produce $3 \times$ as many offspring as the closely related C. halophilus (Danforth et al. 2019), an increase in abundance and range of the species are likely to continue. This has already been seen in Europe, with one study showing that the number of grid cells occupied by the species in Europe had increased by 6 to sevenfold between 2001 and 2010 (Dellicour et al. 2014). This rapid expansion is perhaps surprising, due to the species apparent reliance on a single plant species. However, its dependence is on a common plant species and the warmer summers much of Europe has experienced over the last few decades may have contributed to the production of more abundant and longer lasting flower stands of ivy as it reproduces vegetatively in colder climates (Iversen 1944). More research is required to understand how the increasing number of this invasive species may impact the local pollinator community. This is especially true due to the expanding nature of the species throughout Britain, and other parts of its range.

\section{Conclusion}

In conclusion, ivy pollen has been identified as a crucial floral resource for $C$. hederae in this study. This is shown through the high proportion of ivy pollen collected by females, the matched phenology of female activity and ivy bloom intensity, and that $C$. hederae are the most common insect foraging on ivy during their flight season. This study has only focussed on three locations all in the South of England, well within the species expanded range. Future work in a range of locations is needed to identify if $C$. hederae foraging patterns are consistent throughout where it is found. Also, future research on the potential of competition between this invasive and our native species is required to determine what impact, if any, their presence is having.

Acknowledgements The authors would like to thank the owners of the properties in Lewes where the aggregations were located for allowing us to access their properties. They would also like to thank Natalie Cook for her help with data collection. Thank you, Gatwick Airport and The University of Sussex Doctoral School, for funding the research and thank you to the reviewers for their insightful and helpful comments.

\section{Compliance with ethical standards}

Conflict of interest None of the authors involved in this research have any conflicts of interest to declare.

Open Access This article is licensed under a Creative Commons Attribution 4.0 International License, which permits use, sharing, adaptation, distribution and reproduction in any medium or format, as long as you give appropriate credit to the original author(s) and the source, provide a link to the Creative Commons licence, and indicate if changes were made. The images or other third party material in this article are included in the article's Creative Commons licence, unless indicated otherwise in a credit line to the material. If material is not included in the article's Creative Commons licence and your intended use is not 
permitted by statutory regulation or exceeds the permitted use, you will need to obtain permission directly from the copyright holder. To view a copy of this licence, visit http://creativecommons.org/licenses/by/4.0/.

\section{References}

Barnett LK, Warren MS (1995) High Brown fritillaryArgynnis Adippe. Butterfly Conservation, Wareham

Balfour NJ, Gandy S, Ratnieks FL (2015) Exploitative competition alters bee foraging and flower choice. Behav Ecol Sociobiol 69(10):1731-1738

Bischoff I (2003) Foraging strategy and pollen preferences of Andrena vaga (Panzer) and Colletes ciinicularius (L.) (Hymenoptera: Apidae). Int Soc Hymenopterists 12:220-237

Bischoff I, Eckelt E, Kuhlmann M (2005) On the biology of the ivybee Colletes hederae Schmidt \& Westrich, 1993 (Hymenoptera, Apidae). Bonner Zoologische Beiträge 53:27-36

BWARS (2011) Colletes succinctus. https://www.bwars.com/bee/ colletidae/colletes-succinctus. Accessed 18 May 2020

BWARS (2012) Colletes halophilus. https://www.bwars.com/bee/ colletidae/colletes-halophilus. Accessed 18 May 2020

BWARS (2019) Colletes hederae. https://www.bwars.com/bee/colle tidae/colletes-hederae. Accessed 20 Apr 2020

Cane JH (2020) A brief review of monolecty in bees and benefits of a broadened definition. Apidologie. https://doi.org/10.1007/ s13592-020-00785-y

Cane JH, Sipes S (2006) Characterizing floral specialization by bees: analytical methods and a revised lexicon for oligolecty. Plantpollinator interactions: from specialization to generalization, pp $99-122$

Chittka L, Gumbert A, Kunze J (1997) Foraging dynamics of bumble bees: correlates of movements within and between plant species. Behav Ecol 8:239-249

Clark JR (1983) Age-related changes in trees. J Arboric 9:201-205

Couvillon MJ, Schürch R, Ratnieks FL (2014) Waggle dance distances as integrative indicators of seasonal foraging challenges. PLoS ONE 9(4):e93495

Cross IC (2002) Colletes hederae Schmidt \& Westrich (Hym., Apidae) new to mainland Britain with notes on its ecology in Dorset. Entomol Mon Mag 138:201-203

Danforth BN, Minckley RL, Neff JL, Fawcett F (2019) The solitary bees: biology, evolution, conservation. Princeton University Press, Princeton

Davies CR, Gilbert N (1985) A comparative study of the egg-laying behaviour and larval development of Pieris rapae L. and $P$. brassicae L. on the same host plants. Oecologia 67:278-281

Davis HK, Miller DL, Thetford M (2020) Habitat suitability of an at-risk, monolectic, ground-nesting bee Hesperapis oraria and its floral host Balduina angustifolia at two spatial scales along the Northern Gulf of Mexico. J Insect Conserv 24:561-573

Dellicour S, Mardulyn P, Hardy OJ, Hardy C, Roberts SPM, Vereecken NJ (2014) Inferring the mode of colonization of the rapid range expansion of a solitary bee from multilocus DNA sequence variation. J Evol Biol 27:116-132

Falk S, Lewington R (2015) Field guide to the bees of great Britain and Ireland. Bloomsbury Publishing, London, UK

Free JB (1963) The flower constancy of honeybees. J Anim Ecol 32:119-131

Garbuzov M, Ratnieks FL (2014) Ivy: an underappreciated key resource to flower-visiting insects in autumn. Insect Conserv Divers 7:91-102

Gathmann A, Tscharntke T (2002) Foraging ranges of solitary bees. J Anim Ecol 71:757-764
Gathmann A, Greiler HJ, Tscharntke T (1994) Trap-nesting bees and wasps colonizing set-aside fields: succession and body size, management by cutting and sowing. Oecologia 98:8-14

González-Varo JP, Ortiz-Sanchez FJ, Vilà M (2016) Total bee dependence on one flower species despite available congeners of similar floral shape. PLoS ONE 11(9):e0163122

Goulson D (2003) Effects of introduced bees on native ecosystems. Annu Rev Ecol Evol Syst 34:1-26

Graham KK, Eaton K, Obrien I, Starks PT (2019) Anthidium manicatum, an invasive bee, excludes a native bumble bee, Bombus impatiens, from floral resources. Biol Invasions 21:1089-1099

Grant V (1950) The flower constancy of bees. Bot Rev 16:379-398

Greenleaf SS, Williams NM, Winfree R, Kremen C (2007) Bee foraging ranges and their relationship to body size. Oecologia 153:589-596

Hennessy G, Balfour NJ, Shackleton K, Goulson D, Ratnieks FL (2020) Stinging risk and sting pain of the ivy bee, Colletes hederae. J Apic Res 59:223-231

Henry M, Rodet G (2018) Controlling the impact of the managed honeybee on wild bees in protected areas. Sci Rep 8:1-10

Herbertsson L, Lindström SA, Rundlöf M, Bommarco R, Smith HG (2016) Competition between managed honeybees and wild bumblebees depends on landscape context. Basic Appl Ecol 17:609-616

Hickman JM, Lövei GL, Wratten SD (1995) Pollen feeding by adults of the hoverfly Melanostoma fasciatum (Diptera: Syrphidae). N Z J Zool 22:387-392

Hudewenz A, Klein AM (2015) Red mason bees cannot compete with honey bees for floral resources in a cage experiment. Ecol Evol 5(21):5049-5056

Iversen J (1944) Viscum, Hedera and Ilex as climate indicators: A contribution to the study of the post-glacial temperature climate. Geologiska Föreningen i Stockholm Förhandlingar 66:463-483

Johnson MD (1984) The pollen preferences of Andrena (Melandrena) dunningi Cockerell (Hymenoptera: Andrenidae). J Kansas Entomol Soc 57:34-43

Kéry M, Matthies D, Fischer M (2001) The effect of plant population size on the interactions between the rare plant Gentiana cruciata and its specialized herbivore Maculinea rebeli. J Ecol 89:418-427

Konarska A (2014) Characteristics of flower nectaries of Hedera helix L. (Araliaceae). Acta Sci Pol Hortorum Cultus 13:109-122

Köppler K, Vorwohl G, Koeniger N (2007) Comparison of pollen spectra collected by four different subspecies of the honey bee Apis mellifera. Apidologie 38:341-353

Larson BMH, Kevan PG, Inouye DW (2001) Flies and flowers: taxonomic diversity of anthophiles and pollinators. Can Entomol 133:439-465

Larsson M, FranzEN M (2008) Estimating the population size of specialised solitary bees. Ecol Entomol 33:232-238

McAllister HA (1990) Hedera helix L. and H. hibernica (Kirchner) bean (Araliaceae) in the British Isles

Metcalfe DJ (2005) Hedera helix L. J Ecol 93(3):632-648

Minckley RL, Roulston TH (2006) Incidental mutualisms and pollen specialization among bees. In: Waser NW, Ollteron J (eds) Plantpollinator interactions: from specialization to generalization. University of Chicago Press, Chicago, pp 69-98

Minckley RL, Wcislo WT, Yanega D, Buchmann SL (1994) Behavior and phenology of a specialist bee (Dieunomia) and sunflower (Helianthus) pollen availability. Ecology 75:1406-1419

Müller A, Kuhlmann M (2008) Pollen hosts of western palaearctic bees of the genus Colletes (Hymenoptera: Colletidae): the Asteraceae paradox. Biol J Lin Soc 95:719-733

Nicolson SW (2011) Bee food: the chemistry and nutritional value of nectar, pollen and mixtures of the two. Afr Zool 46:197-204 
Norris MJ (1936) The feeding-habits of the adult Lepidoptera Heteroneura. Trans R Entomol Soc Lond 85:61-90

Ogilvie JE, Forrest JR (2017) Interactions between bee foraging and floral resource phenology shape bee populations and communities. Curr Opin Insect Sci 21:75-82

Ritchie AD, Ruppel R, Jha S (2016) Generalist behavior describes pollen foraging for perceived oligolectic and polylectic bees. Environ Entomol 45:909-919

Sawyer R, Pickard RS (1981) Pollen identification for beekeepers. University College Cardiff Press, Cardiff

Schäffler I, Dötterl S (2011) A day in the life of an oil bee: phenology, nesting, and foraging behavior. Apidologie 42:409-424

Schmidt K, Westrich P (1993) Colletes hederae n. sp., eine bisher unerkannte, auf Efeu (Hedera) spezialisierte Bienenart (Hymenoptera: Apoidea). Entomol Z 103:89-112

Seeley TD (1982) How honeybees find a home. Sci Am 247:158-169

Seeley TD (2009) The wisdom of the hive: the social physiology of honey bee colonies. Harvard University Press, Cambridge

Sommeijer MJ, Rooijakkers EF, Jacobusse C, Kerkvliet JD (2009) Larval food composition and food plants of the solitary bee Colletes halophilus (Hymenoptera: Colletidae). J Apic Res 48:149-155

Teppner H, Brosch U (2015) Pseudo-oligolecty in Colletes hederae (Apidae-Colletinae, Hymenoptera). Linzer Biol Beitr 47(1):301-306
Vanderplanck M, Vereecken NJ, Grumiau L, Esposito F, Lognay G, Wattiez R, Michez D (2017) The importance of pollen chemistry in evolutionary host shifts of bees. Sci Rep 7:43058

Wcislo WT, Cane JH (1996) Floral resource utilization by solitary bees (Hymenoptera: Apoidea) and exploitation of their stored foods by natural enemies. Annu Rev Entomol 41(1):257-286

Westrich P (2008) Flexibles Pollensammelverhalten der ansonsten streng oligolektischen Seidenbiene Colletes hederae Schmidt \& Westrich (Hymenoptera: Apidae). Eucera 1:17-29

Wignall VR, Brolly M, Uthoff C, Norton KE, Chipperfield HM, Balfour NJ, Ratnieks FL (2020) Exploitative competition and displacement mediated by eusocial bees: experimental evidence in a wild pollinator community. Behav Ecol Sociobiol 74:1-15

Publisher's Note Springer Nature remains neutral with regard to jurisdictional claims in published maps and institutional affiliations. 